\title{
Kinetic modeling of antimony(III) oxidation and sorption in soils
}

\author{
Yongbing Cai ${ }^{\mathrm{a}, \mathrm{b}}$, Yuting $\mathrm{Mi}^{\mathrm{c}}$, Hua Zhang ${ }^{\mathrm{a}, *}$ \\ ${ }^{a}$ Key Laboratory of Coastal Zone Environmental Processes and Ecological Remediation, Yantai Institute of Coastal Zone Research, Chinese Academy of \\ Sciences, Yantai, Shandong, China \\ b University of Chinese Academy of Sciences, Beijing, China \\ ' School of Environment and Materials Engineering, Yantai University, Yantai, Shandong, China
}

\section{H I G H L I G H T S}

- Extensive retention and oxidation of $\mathrm{Sb}(\mathrm{III})$ in two soils with contrasting properties.

- Soil serve as a catalyst in promoting oxidation of $\mathrm{Sb}(\mathrm{III})$ even under anaerobic conditions.

- Transport of $\mathrm{Sb}(\mathrm{III})$ is governed by sorption-oxidation process on soil surfaces.

- The equilibrium-kinetic sorption and kinetic oxidation formulations successfully described $\mathrm{Sb}(\mathrm{III})$ reactions on soils.

\section{A R T I C L E I N F O}

\section{Article history:}

Received 1 February 2016

Received in revised form 8 May 2016

Accepted 9 May 2016

Available online 10 May 2016

\section{Keywords:}

Antimony(III)

Soil

Oxidation

Adsorption

Transport

\section{G R A P H I C A L A B S T R A C T}

Observed-Sb(III) - Simulated-Sb(III) O Observed-Sb(V) - - - Simulated-Sb(V)
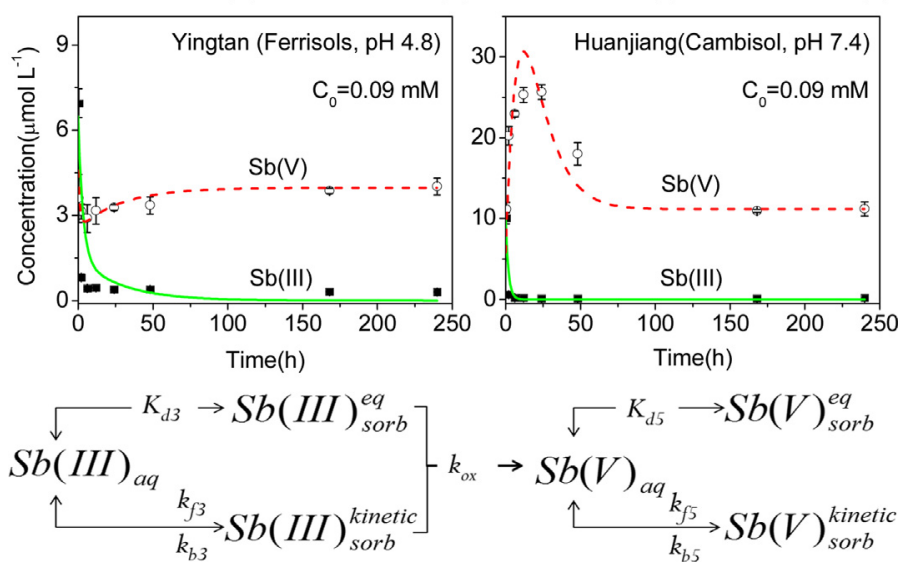

\section{A B S T R A C T}

Kinetic batch and saturated column experiments were performed to study the oxidation, adsorption and transport of $\mathrm{Sb}(\mathrm{III})$ in two soils with contrasting properties. Kinetic and column experiment results clearly demonstrated the extensive oxidation of $\mathrm{Sb}(\mathrm{III})$ in soils, and this can in return influence the adsorption and transport of $\mathrm{Sb}$. Both sorption capacity and kinetic oxidation rate were much higher in calcareous Huanjiang soil than in acid red Yingtan soil. The results indicate that soil serve as a catalyst in promoting oxidation of $\mathrm{Sb}$ (III) even under anaerobic conditions. A PHREEQC model with kinetic formulations was developed to simulate the oxidation, sorption and transport of $\mathrm{Sb}$ (III) in soils. The model successfully described $\mathrm{Sb}$ (III) oxidation and sorption data in kinetic batch experiment. It was less successful in simulating the reactive transport of $\mathrm{Sb}$ (III) in soil columns. Additional processes such as colloid facilitated transport need to be quantified and considered in the model.

(C) 2016 Elsevier B.V. All rights reserved.

\footnotetext{
* Corresponding author.

E-mail address: hzhang@yic.ac.cn (H. Zhang).
}

\section{Introduction}

Antimony $(\mathrm{Sb})$ and its compounds are considered to be pollutants of priority interest by the United States Environmental Protection Agency [1] and the European Union [2] because of their toxicity and suspected carcinogenicity for humans [3-6]. In general, 


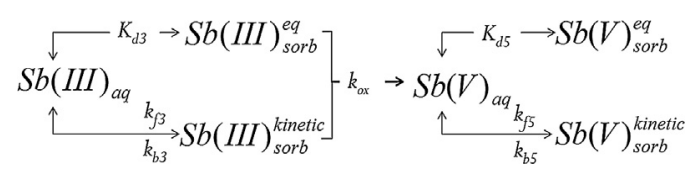

Fig. 1. A schematic diagram of the model. Here $S b(I I I)_{a q}$ and $S b(V)_{a q}$ are dissolved $\mathrm{Sb}(\mathrm{III})$ and $\mathrm{Sb}(\mathrm{V})$ in solution, $\mathrm{Sb}(\mathrm{III})_{\text {sorb }}^{e q}$ and $\mathrm{Sb}(\mathrm{V})_{\text {sorb }}^{e q}$ are $\mathrm{Sb}(\mathrm{III})$ and $\mathrm{Sb}(\mathrm{V})$ adsorbed on equilibrium sites, respectively, $S b(I I I)_{\text {sorb }}^{\text {kinetic }}$ and $S b(V)_{\text {sorb }}^{\text {kinetic }}$ are $\mathrm{Sb}(\mathrm{III})$ and $\mathrm{Sb}(\mathrm{V})$ adsorbed on kinetic sites, respectively, where $K_{d 3}, K_{d 5}, k_{f 3}, k_{b 3}, k_{f 5}, k_{b 5}$, and $k_{o x}$ are the respective rates of reactions.

the natural abundance of $\mathrm{Sb}$ is low, $0.2-2 \mu \mathrm{g} \mathrm{g}^{-1}$ in sediment rocks, $<1 \mu \mathrm{g} \mathrm{L}^{-1}$ in natural water, and a few $\mu \mathrm{g} \mathrm{g}^{-1}$ in sediments and soils $[2,7]$. Because of $\mathrm{Sb}$ is frequently used in a variety of industrial products such as $\mathrm{Sb}$ (III) in flame retardants and elemental $\mathrm{Sb}$ in alloys for storage batteries and ammunition [8,9], elevated concentrations of $\mathrm{Sb}$ are found in soil and water around mining and smelting sites, at shooting ranges, and along roadsides [10-13]. As the biggest Sb producer, China has suffered serious $\mathrm{Sb}$ pollution in several regions where soils were highly enriched in Sb [9] with concentration up to thousand times of natural background (a few $\mu \mathrm{gg}^{-1}$ ) [2].

Although field and laboratory experiments have been carried out to investigate the environmental behaviors of $\mathrm{Sb}$, there are still substantial knowledge gaps on the mobility of $\mathrm{Sb}$ (III) in soils [2]. In the natural environment, $\mathrm{Sb}(\mathrm{V})$ is the predominant species and exists as $\mathrm{Sb}(\mathrm{OH})_{6}{ }^{-}$in oxic environments, and $\mathrm{Sb}(\mathrm{III})$ primarily occurs as $\mathrm{Sb}(\mathrm{OH})_{3}$ and is more stable and toxic under anaerobic conditions between $\mathrm{pH} 2$ and 10 [2,7]. Understanding Sb speciation in soils and aquatic systems is important for assessing its fate and risk, because the mobility and toxicity of Sb greatly depend on its oxidation state. However, up to date most of the studies on Sb were only considered $\mathrm{Sb}(\mathrm{V})$ retention in natural minerals and soils, few considered the oxidation reaction of $\mathrm{Sb}(\mathrm{III})$ in soils in the process of transport [14-17]. Earlier studies have studied the influence of dissolved molecular oxygen and hydrogen peroxide, iodate, natural minerals (Fe-Mn oxyhydroxides, etc.) on the oxidation of $\mathrm{Sb}$ (III) to $\mathrm{Sb}(\mathrm{V})[12,18-24]$. These studies indicated that natural minerals with large surface areas not only can adsorb Sb strongly but also acting as oxidants in transforming $\mathrm{Sb}(\mathrm{III})$ to $\mathrm{Sb}(\mathrm{V})$. Photoirradiation of natural water samples spiked with $\mathrm{Sb}$ (III) showed that the oxidation rates could be well predicted based on DOC [25]. Mitsunobu et al. [26] have studied Sb behavior under various redox conditions in soils, they found that $\mathrm{Sb}(\mathrm{V})$ is a stable oxidation state even under reducing condition ( $\mathrm{Eh}=-180 \mathrm{mV}, \mathrm{pH} 8$ ) and $\mathrm{Sb}$ is oxidized at lower Eh than arsenic. Interestingly, using $\mu$-XANES method Mitsunobu et al. [27] proved that Sb reduction occurred in reducing soil which can be an important factor for Sb immobilization under reducing conditions, since the $\mathrm{Sb}(\mathrm{III})$ sorbs more strongly on $\mathrm{Fe}(\mathrm{III})$ hydroxides than $\mathrm{Sb}(\mathrm{V})$ and its solubility is also much lower than that of $\mathrm{Sb}(\mathrm{V})$ species. However, to our knowledge the redox chemistry of $\mathrm{Sb}$ in natural soil-water systems is still unclear. Furthermore, although Zhang et al. [28] have proven numerical models incorporating kinetic reactions and transport processes was capable of simulating $\mathrm{Sb}(\mathrm{V})$ transport in soil columns, their capability in simulating the retention and transport of $\mathrm{Sb}(\mathrm{III})$ in soils has not been evaluated.

In this study, kinetic batch and column transport experiments were carried out to (1) quantify the kinetics of oxidation and adsorption of $\mathrm{Sb}(\mathrm{III})$ in two soils with contrasting properties; (2) evaluate the mobility of $\mathrm{Sb}(\mathrm{III})$ in soils with miscible-displacement experiments; and (3) develop a reactive transport model to simulate the movement of $\mathrm{Sb}(\mathrm{III})$ in soils for risk assessment of $\mathrm{Sb}$ exposure. Understanding the mechanism of $\mathrm{Sb}(\mathrm{III})$ oxidation by soil is helpful in clarifying the fate and geochemical cycling of Sb in the environment. This study will provide essential information for eval- uating the environmental risks associated with Sb transformation and mobilization at contaminated sites.

\section{Material and methods}

\subsection{Soils and reagents}

The studied samples of an acid red soil (Yingtan) and a calcareous soil (Huanjiang) were collected from Yingtan Red Soil Ecological Experiment Station and Huanjiang Observation and Research Station for Karst Ecosystems, respectively (for details, see the Supplementary Material). The chemicals used were of analytical grade or guaranteed grade (for details, see the Supplementary Material).

\subsection{Batch experiments}

Sorption isotherms on the two soils were determined using batch experiments at room temperature $\left(25^{\circ} \mathrm{C}\right)$ under aerobic conditions [29]. The initial concentrations $\left(\mathrm{C}_{0}\right)$ of $\mathrm{Sb}_{\text {tot }}$ were 0.009 , $0.047,0.094,0.472$, and $0.944 \mathrm{mM}$. Experiments were initiated by mixing $3.0 \mathrm{~g}$ of soil with $30 \mathrm{~mL}$ of Sb solution in 50 -mL Teflon tubes. The mixtures were shaken at $200 \mathrm{rpm}$ on a reciprocal shaker for $48 \mathrm{~h}$ and subsequently centrifuged for $10 \mathrm{~min}$ at $4000 \mathrm{rpm}$ before sampling.

To determine extent of time-dependent sorption and oxidation kinetic, batch experiments were initiated with three initial concentrations $C_{0}(0.09,0.47$, and $0.94 \mathrm{mM})$ of $\mathrm{Sb}_{\text {tot }}$. The mixtures were sampled at reaction times of $0.5,2,6,12,24,48$, 168 , and $240 \mathrm{~h}$. Samples for $\mathrm{Sb}$ (III) analysis were stabilized in $0.5 \mathrm{M}$ disodium-hydrogen-citrate solution, and samples for $\mathrm{Sb}_{\text {tot }}$ $\left(\mathrm{Sb}_{\text {tot }}=\mathrm{Sb}(\mathrm{III})+\mathrm{Sb}(\mathrm{V})\right)$ determination were stabilized in $3 \mathrm{M} \mathrm{HCl}$ solution [19]. Amount of $\mathrm{Sb}_{\text {tot }}$ adsorption was calculated from the difference between concentrations of the supernatant and that of the initial solutions. For each input concentration $C_{0}$, the tests were performed in triplicates and the mean and standard error (SE) of the amount of $\mathrm{Sb}(\mathrm{III})$ and $\mathrm{Sb}_{\text {tot }}$ adsorbed is reported.

\subsection{Miscible displacement experiments}

The saturated miscible displacement technique was used to investigate the reactive transport of $\mathrm{Sb}$ (III) in soils [30,31]. Two acrylic columns (8.5- $\mathrm{cm}$ in length and of $2.5-\mathrm{cm}$ i.d.) were uniformly packed with Yingtan and Huanjiang soil samples. Soil bulk density of Yingtan soil was $1.36 \mathrm{~g} \mathrm{~cm}^{-3}$ which is a little higher than Huanjiang soil of $1.19 \mathrm{~g} \mathrm{~cm}^{-3}$. Pore volume of Yingtan and Huanjiang soils in the columns were 21 and $24 \mathrm{~mL}$ respectively. Two columns were slowly water saturated with background solution at a low Darcy flux until effluent $\mathrm{pH}$ reached steady state, about 4.0 for red soil and 7.9 for calcareous soil. Input solution of $0.094 \mathrm{mM}$ $\mathrm{Sb}_{\text {tot }}$ was subsequently introduced to each soil column at constant flow rate (about $7 \mathrm{~mL} \mathrm{~h}^{-1}$ ) with a peristaltic pump (BT 102S, Baoding Longer Precision Pump Co., Ltd., Hebei, China). The Sb solution was continuous purging of nitrogen gas throughout the whole process of experiment and the purity of nitrogen gas was $99.95 \%$. A leaching or desorption pulse consists of pumping the background solution was conducted after applying Sb solution. Effluent samples were collected from the outlet of the column by an automatic effluent fraction collector (CBS-A, Shanghai Huxi Analysis Instrument Factory Co., Ltd., Shanghai) at $1 \mathrm{~h}$ time interval.

Concentrations of $\mathrm{Sb}(\mathrm{III})$ and $\mathrm{Sb}_{\text {tot }}$ were analyzed using Hydride Generation Atomic Fluorescence Spectrometer (AFS-930, Beijing jitian Instrument Factory Co., Ltd., Beijing) [19], and the concentration of $\mathrm{Sb}(\mathrm{V})$ was calculated from the difference of $\mathrm{Sb}_{\text {tot }}$ and $\mathrm{Sb}(\mathrm{III})$ concentrations. The $\mathrm{pH}$ of the solutions ( 0.1 units) was measured using a pH meter (Metrohm 713) and a combined glass electrode 
(Metrohm 6.0222.100), which was calibrated with buffer solutions (Merck).

\subsection{Modeling}

The interactions of $\mathrm{Sb}(\mathrm{III})$ and $\mathrm{Sb}(\mathrm{V})$ with the soils were modeled using the computer program PHREEQC [32]. The model assumes that $\mathrm{Sb}(\mathrm{V}) / \mathrm{Sb}(\mathrm{III})$ is retained on soil at a set of equilibrium sorption sites interacts instantaneously and a set of reversible kinetic sites are time dependent in nature. The oxidation of $\mathrm{Sb}(\mathrm{III})$ to $\mathrm{Sb}(\mathrm{V})$ occur only on soil surface and the oxidation kinetics is linearly related to adsorbed $\mathrm{Sb}$ (III) (Fig. 1). The model can be described in the following formulations:

$S_{\mathrm{Sb}(I I I) \mathrm{eq}}=K_{d 3} C_{S b(I I I)}$

$\frac{\partial S_{S \mathrm{~b}(I I I) k}}{\partial t}=k_{f 3} C_{S b(I I I)}-k_{b 3} S_{S b(I I I) k}$

$S_{S \mathrm{~b}(V) \mathrm{eq}}=K_{d 5} C_{S b(V)}$

$\frac{\partial S_{S \mathrm{~b}(V) k}}{\partial t}=k_{\mathrm{f} 5} C_{S b(V)}-k_{b 5} S_{S b(V) k}$

$\frac{\partial C_{S b(V)}}{\partial t}=k_{o x} S_{S b(I I I)}$

Here $S_{S b(I I I) e q}$ and $S_{S b(V) e q}$ are the $\mathrm{Sb}(\mathrm{III})$ or $\mathrm{Sb}(\mathrm{V})$ retained on equilibrium sites ( $\left.\mu \mathrm{mol} \mathrm{g}^{-1}\right), S_{S b(I I) k}$ and $S_{S b(V) k}$ are the $S b(I I I)$ or $\mathrm{Sb}(\mathrm{V})$ retained on kinetic type sites $\left(\mu \mathrm{molg}^{-1}\right), S_{S b(I I I)}$ is the sum of $S_{S b(I I) e q}$ and $S_{S b(I I I) k}$ that is all $\mathrm{Sb}$ (III) retained on soil surface ( $\left.\mu \mathrm{mol} \mathrm{g}^{-1}\right), C_{S b(I I I)}$ and $C_{S b(V)}$ are the $\mathrm{Sb}(\mathrm{III})$ and $\mathrm{Sb}(\mathrm{V})$ concentration in solution $\left(\mu \mathrm{mol} \mathrm{L}^{-1}\right), K_{d 3}$ and $K_{d 5}$ are the equilibrium distribution coefficient, $k_{f 3}, k_{f 5}$ and $k_{b 3}, k_{b 5}\left(\mathrm{~h}^{-1}\right)$ are the forward and backward reaction rates associated with kinetic sites, respectively, $k_{o x}$ is the oxidation rate of $\mathrm{Sb}$ (III) on soil surface, $t$ is reaction time. To simulate the reactive transport of $\mathrm{Sb}(\mathrm{III})$ and $\mathrm{Sb}(\mathrm{V})$ through soils, the kinetic reaction formulations are incorporated into the steady state convection-dispersion equation (CDE) in the form of:

$\frac{\partial C_{S \mathrm{~b}(I I I)}}{\partial t}+\frac{\partial S_{S b(I I I)}}{\partial t}=\frac{\partial}{\partial x}\left(D \frac{\partial C_{S \mathrm{~b}(I I I)}}{\partial x}\right)-v \frac{\partial C_{S \mathrm{~b}(I I I)}}{\partial x}$

$\frac{\partial C_{S \mathrm{~b}(V)}}{\partial t}+\frac{\partial S_{S b(V)}}{\partial t}=\frac{\partial}{\partial x}\left(D \frac{\partial C_{S \mathrm{~b}(V)}}{\partial x}\right)-v \frac{\partial C_{S \mathrm{~b}(V)}}{\partial x}$

where $x$ is distance $(\mathrm{cm})$, $\mathrm{D}$ is hydrodynamic dispersion coefficient $\left(\mathrm{cm}^{2} \mathrm{~h}^{-1}\right)$, and $\mathrm{v}$ is pore water velocity $\left(\mathrm{cm} \mathrm{h}^{-1}\right)$.

\section{Results and discussion}

\subsection{Sorption isotherms}

Langmuir and Freundlich models were used to fit our experimental adsorption data for describing the distribution of $\mathrm{Sb}_{\text {tot }}$ between aqueous $(C)$ and two soils $(S)$, the corresponding sorption parameters were derived by plotting the linear forms of both isotherms. The results are shown in Fig. 2 and Table 1. The Freundlich equation can be expressed as $S=K_{F} C^{N}$, where $S$ represents the amount of adsorption $\left(\mu \mathrm{mol} \mathrm{g}^{-1}\right), K_{F}$ is the Freundlich distribution or partition coefficient $\left(\mathrm{Lg}^{-1}\right), C$ is equilibrium concentration

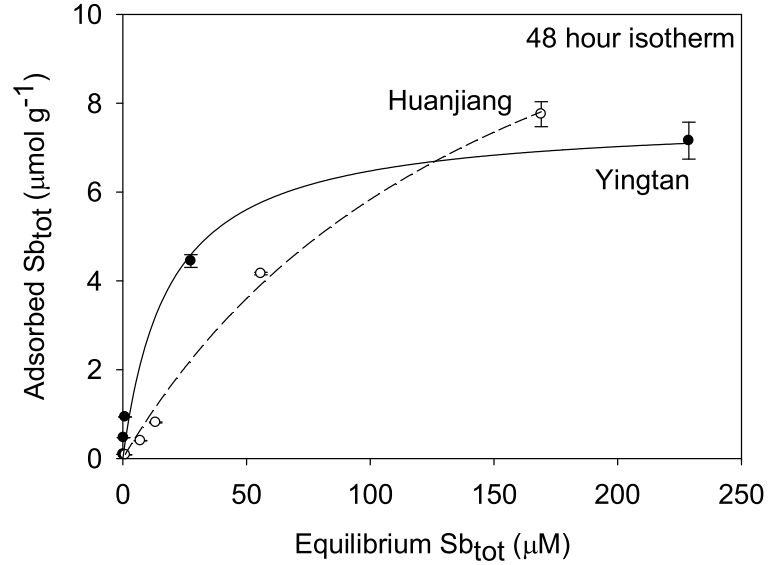

Fig. 2. Sorption isotherms of $\mathrm{Sb}_{\text {tot }}$. The solid and dashed lines depict results of curvefitting with the Langmuir model. The experiments was performed by $48 \mathrm{~h}$ reaction of $3 \mathrm{~g}$ soil with $30 \mathrm{~mL}$ Sb solutions at different initial concentrations.

( $\mu \mathrm{mol} \mathrm{L}^{-1}$ ), and $N$ is the dimensionless reaction order. The Langmuir equation is another widely use equilibrium sorption model which has the advantage of providing a sorption maximum $S_{\max }$ $\left(\mu \mathrm{mol} \mathrm{g}^{-1}\right.$ ) that can be correlated to sorbed phases sorption properties. The Langmuir equation has the form $S=S_{\max } \frac{K_{L} C}{1+K_{L} C}$, where $K_{L}$ $\left(\mathrm{L} \mu \mathrm{mol}^{-1}\right.$ ) is a Langmuir coefficient related to the binding strength, $C$ is equilibrium concentration $\left(\mu \mathrm{mol} \mathrm{L}^{-1}\right)$. The Langmuir isotherm model assumes that all adsorption sites have equal affinity for the adsorbate and therefore only monolayer adsorption occurs while the Freundlich isotherm is based on the assumption of heterogeneous surfaces with different affinities that is have multilayer adsorption [33].

Fig. 2 clearly exhibit the nonlinear adsorption behavior of $\mathrm{Sb}$, which is characterized by the low values of the Freundlich nonlinear reaction order for Yingtan $(N=0.32 \pm 0.05)$ and Huanjiang $(N=0.73 \pm 0.10)$ soil. The two models were well fitted the adsorption of $\mathrm{Sb}_{\text {tot }}$ on the two soils which have high regression coefficients (>0.975) for all cases (Table 1 ). A comparison between the Langmuir parameters demonstrated that the maximum adsorption of $\mathrm{Sb}_{\text {tot }}$ on Huanjiang soil $\left(15.30 \pm 2.40 \mu \mathrm{mol} \mathrm{g}^{-1}\right)$ was about two times of the Yingtan soil $\left(7.67 \pm 0.56 \mu \mathrm{mol} \mathrm{g}^{-1}\right)$. Several studies have found that soil properties including metal content, organic matter as potential controlling factors of Sb retention and transport in soils $[17,34,35]$. This is consistent with the soil characteristics that there are more TOC and iron and manganese oxides in the Huanjiang soil than the Yingtan soil. While the adsorption amount of $\mathrm{Sb}_{\text {tot }}$ on Huanjiang soil was a little lower than Yingtan soil at the lower initial concentrations, and at the highest initial concentration the adsorption amount on Huanjiang soil was much higher (Fig. 2). The adsorption isotherms of $\mathrm{Sb}_{\text {tot }}$ in Fig. 2 was different from $\mathrm{Sb}(\mathrm{V})$ adsorption results from our previous study [28], which showed that the adsorption of $\mathrm{Sb}(\mathrm{V})$ in Yingtan soil was much higher than in Huanjiang soil. This is because that $\mathrm{Sb}(\mathrm{V})$ adsorption was dramatically influenced by solution $\mathrm{pH}$ while $\mathrm{Sb}$ (III) can be adsorbed in a wide range of $\mathrm{pH}$ [35].

$\mathrm{Sb}(\mathrm{III})$ and $\mathrm{Sb}(\mathrm{V})$ concentrations in the equilibrium solution after sorption isotherms experiment are shown in Fig. 3 illustrate that

Table 1

Estimated Freundlich- and Langmuir- parameters for $\mathrm{Sb}_{\mathrm{tot}}$ adsorption.

\begin{tabular}{|c|c|c|c|c|c|c|c|}
\hline & & Langmuir & & & Freundlich & & \\
\hline $\mathrm{Sb}$ & Soil & $S_{\max } \mu \mathrm{molg}^{-1}$ & $K_{L} \mathrm{~L} \mu \mathrm{mol}^{-1}$ & $\mathrm{R}^{2}$ & $K_{F} \quad \mathrm{Lg}^{-1}$ & $N$ & $\mathrm{R}^{2}$ \\
\hline \multirow[t]{2}{*}{$\mathrm{Sb}_{\text {tot }}$} & Yingtan & $7.67 \pm 0.56$ & 0.054 & 0.987 & $1.27 \pm 0.32$ & $0.32 \pm 0.05$ & 0.975 \\
\hline & Huanjiang & $15.30 \pm 2.40$ & 0.006 & 0.994 & $0.189 \pm 0.09$ & $0.73 \pm 0.10$ & 0.982 \\
\hline
\end{tabular}



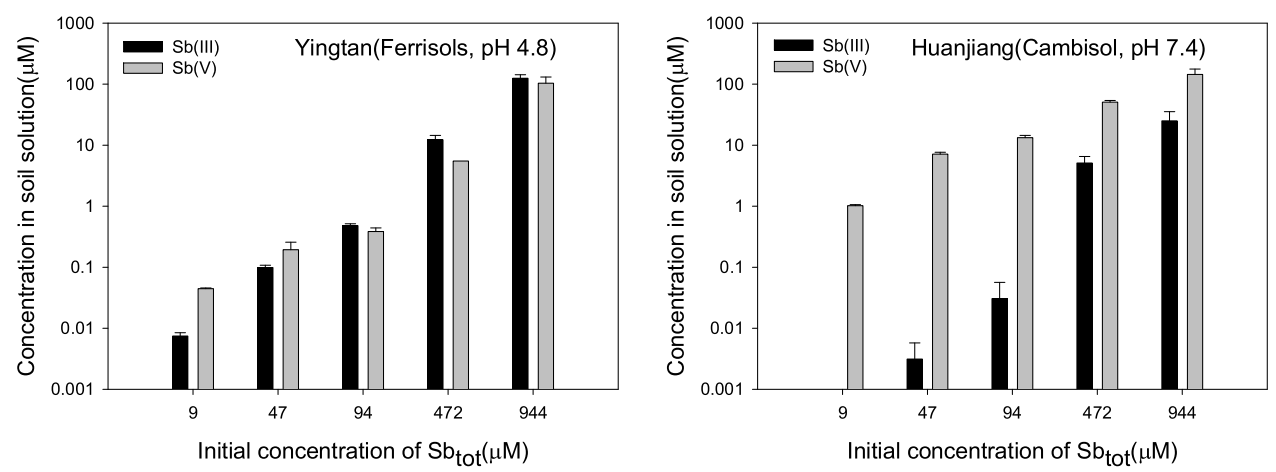

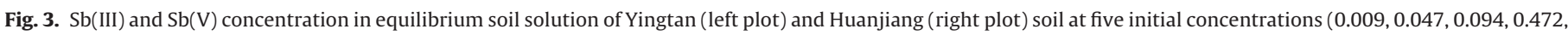
and $0.944 \mathrm{mM})$, the black and gray bars depict $\mathrm{Sb}(\mathrm{III})$ and $\mathrm{Sb}(\mathrm{V})$ concentrations in soil solutions, respectively.

abundant of $\mathrm{Sb}(\mathrm{V})$ existed especially in the Huanjiang soil solution. At the three lower initial concentrations, almost all Sb sorbed in Yingtan soil with little $\mathrm{Sb}(\mathrm{V})$ released but there was more $\mathrm{Sb}(\mathrm{V})$ released in Huanjiang soil. At the two higher initial concentrations, about $50 \%$ of $\mathrm{Sb}_{\text {tot }}$ was $\mathrm{Sb}$ (III) in the Yingtan soil solutions, and in the Huanjiang soil solutions $\mathrm{Sb}$ (III) was less than $20 \%$ of $\mathrm{Sb}_{\text {tot. }}$. The difference between the two soils may because of the physical and chemical characteristics, especially the TOC and Fe-Mn oxides contents and the $\mathrm{pH}$ in the solution. As earlier studies have indicated that content of TOC and Fe-Mn oxides dramatically influence adsorption of $\mathrm{Sb}$, and $\mathrm{pH}$ can influence the oxidation rate of $\mathrm{Sb}(\mathrm{III})$ and release of $\mathrm{Sb}(\mathrm{V})$ from soil [12,36,37]. Belzile et al. [24] have studied on the oxidation of $\mathrm{Sb}$ (III) in presence of natural and synthetic iron and manganese oxyhydroxides, indicated that $\mathrm{Sb}(\mathrm{III}) \mathrm{can}$ rapidly be oxidized to $\mathrm{Sb}(\mathrm{V})$ by them. So the existence of soils we studied here might be one reason of $\mathrm{Sb}$ (III) oxidization, as the two soils have high content of Fe-Mn oxides especially in Huanjiang soil.

\subsection{Kinetic oxidation and sorption}

The results of control experiment where no soil was added clearly demonstrated that concentration of $\mathrm{Sb}(\mathrm{III})$ did not change for $240 \mathrm{~h}$ throughout the experiment (for details, see the Supplementary Material). This may because the compounds (potassium antimony tartrate) that we used to prepare $\mathrm{Sb}$ (III) solution is very stable in aqueous solutions. Calle-Guntiñas et al. [46] had found that $\mathrm{Sb}$ (III) in aqueous solutions stored at room temperature of $25^{\circ} \mathrm{C}$ was not oxidized to $\mathrm{Sb}(\mathrm{V})$ after 3 months using the same compound. Furthermore, The result was also consistent with the study of Belzile et al. [24], where no significant oxidation of $\mathrm{Sb}$ (III) was observed in solution with $\mathrm{O}_{2}$ but without Fe-Mn oxides in the $\mathrm{pH}$ range of 5-10 within 7 days.

The results of kinetic batch experiments are presented in Fig. 4 and Fig. 5. The time series of $\mathrm{Sb}(\mathrm{III})$ and $\mathrm{Sb}(\mathrm{V})$ concentration in Fig. 4 clearly illustrates the oxidation of $\mathrm{Sb}(\mathrm{III})$ and release of $\mathrm{Sb}(\mathrm{V})$ on/from soil surface. Concentration of $\mathrm{Sb}(\mathrm{III})$ in soil solution continuously decreased during the kinetic experiment, while concentration of $\mathrm{Sb}(\mathrm{V})$ in soil solution increased firstly and then decreased. The initial dramatic decrease of $\mathrm{Sb}(\mathrm{III})$ indicated a strong adsorption process. The phenomenon that $\mathrm{Sb}(\mathrm{V})$ increased firstly and then decreased is similar to the results of $\mathrm{As}$ (III) oxidation on aquifer material surfaces [47]. This suggest a multi-step surface adsorption-oxidation process: (1) transport of $\mathrm{Sb}$ (III) to the surface, (2) $\mathrm{Sb}$ (III) adsorption onto the surface sites, (3) oxidation of $\mathrm{Sb}$ (III) to $\mathrm{Sb}(\mathrm{V})$ at the surface, (4) release of produced $\mathrm{Sb}(\mathrm{V})$ from the surface, and (5) $\mathrm{Sb}(\mathrm{V})$ adsorption to other surface sites following its production and release into solution.

Comparison between the two soils revealed that a larger fraction of $\mathrm{Sb}(\mathrm{III})$ was transformed into $\mathrm{Sb}(\mathrm{V})$ in Huanjiang soil than in
Yingtan soil, which is consistent with the result of isotherm adsorption experiment. Our experiments indicated that oxidation of $\mathrm{Sb}(\mathrm{III})$ was slower in Yingtan soil than in Huanjiang soil. The higher $\mathrm{pH}$ of the Huanjiang soil (>7.0) could be one major factor controlling the release of $\mathrm{Sb}(\mathrm{V})$. In addition, the difference in the soil content of manganese oxides might also be a contributing factor to the oxidation capacity of the two soils.

The changes of $\mathrm{Sb}_{\text {tot }}$ adsorption with reaction time shown in Fig. 5 demonstrated that the oxidation-sorption process of $\mathrm{Sb}(\mathrm{III})$ in soils. The rate of $\mathrm{Sb}_{\text {tot }}$ retention was rapid during the earlier stages of reaction and then followed by slow reactions. This is consistent with previous studies which revealed that $\mathrm{Sb}$ adsorption was initially rapid followed by a slow retention rate $[12,19]$. The retention rate of $\mathrm{Sb}$ was rapid at low initial concentrations especially in Yingtan soil solution, which indicated that preferential sorption of $\mathrm{Sb}$ on high energy sites. But in the slow reaction of $\mathrm{Sb}$ adsorption process the adsorption amount of $\mathrm{Sb}_{\text {tot }}$ have a little decrease especially in the Huanjiang soil. This is because of $\mathrm{Sb}(\mathrm{III})$ was oxidized to $\mathrm{Sb}(\mathrm{V})$ on soil surface and then released, and as the extension of the experimental time, $\mathrm{Sb}(\mathrm{V})$ was readsorbed on the soils again. Tighe and Lockwood [38] have reported that $95 \% \mathrm{Sb}(\mathrm{V})$ sorption by a non-crystalline Fe hydroxide across a $\mathrm{pH}$ range of 2.5-7 with a sorption maximum at about $\mathrm{pH}$ 4. Sorption of $\mathrm{Sb}(\mathrm{V})$ on hematite is also strong, with a similar sorption maxima $(\sim \mathrm{pH} 4)$ involving a combination of surface binding sites, similar to arsenic $[39,40]$. At the time of $48 \mathrm{~h}$, the kinetic adsorption amount were $0.91 \pm 0.01,4.12 \pm 0.03,6.10 \pm 0.04 \mu \mathrm{mol} \mathrm{g}^{-1}$ for three initial concentrations of $\mathrm{Sb}$ in the Yingtan soil. While the isotherm adsorption amount were $0.94 \pm 0.01,4.45 \pm 0.20,7.16 \pm 0.59 \mu \mathrm{mol} \mathrm{g}^{-1}$ (Fig. 2) for the same three initial concentrations. The reason of the difference is that in the kinetic experiment more oxygen could involve in the redox process, and this cause more $\mathrm{Sb}$ (III) oxidized and released from soil surface. The phenomenon appeared more significantly in Huanjiang soil, in the kinetic experiment the amount of $\mathrm{Sb}_{\text {tot }}$ was $0.76 \pm 0.01,3.29 \pm 0.03,5.90 \pm 0.06 \mu \mathrm{mol} \mathrm{g}^{-1}$, which is much less than $0.81 \pm 0.01,4.16 \pm 0.03,7.75 \pm 0.28 \mu \mathrm{molg}^{-1}$ (Fig. 2) of the isotherm adsorption experiment.

Our model successfully simulated the oxidation and sorption process of $\mathrm{Sb}(\mathrm{III})$ in the two soils. The modeling results clearly shows that the equilibrium distribution coefficient $K_{d 3}$ and $K_{d 5}$ were higher in Yingtan soil than in Huanjiang soil in the batch experiments at all the three initial concentrations (Table 2). And the higher of the initial concentration, the lower of the equilibrium distribution coefficient. But in the column experiments, the equilibrium distribution coefficient $K_{d 3}$ and $K_{d 5}$ were higher in Huanjiang soil than in Yingtan soil. The sorption reaction rate of $\mathrm{Sb}(\mathrm{III})$ was higher in Huanjiang soil than in Yingtan soil which is contrary to $\mathrm{Sb}(\mathrm{V})$. While the oxidation reaction rate was lower in Yingtan soil than in Huanjiang soil for all of the experiments. In Yingtan soil, 

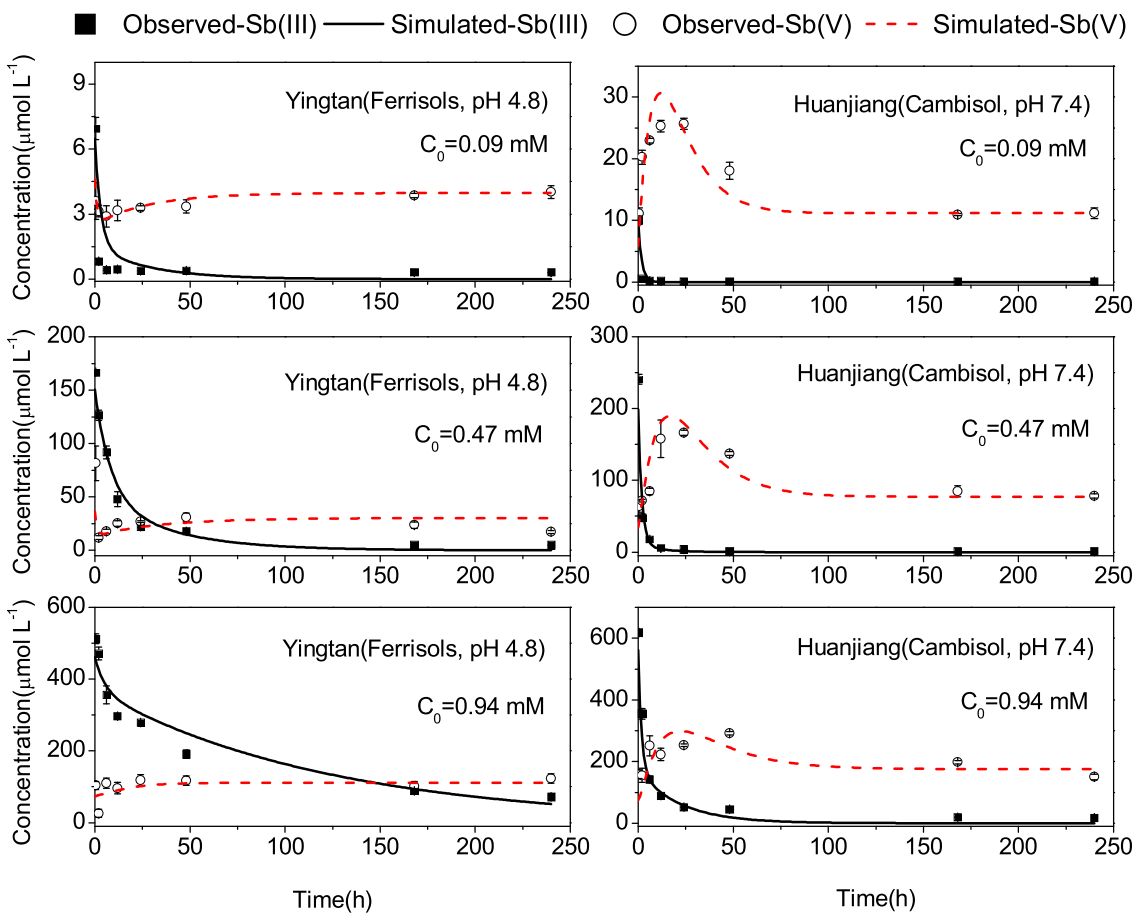

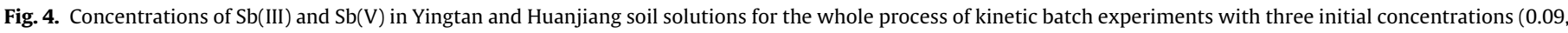

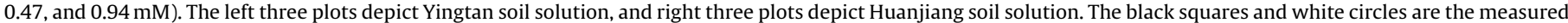
concentrations of $\mathrm{Sb}(\mathrm{III})$ and $\mathrm{Sb}(\mathrm{V})$, respectively. The solid and dash lines are model fits to the experimental data.
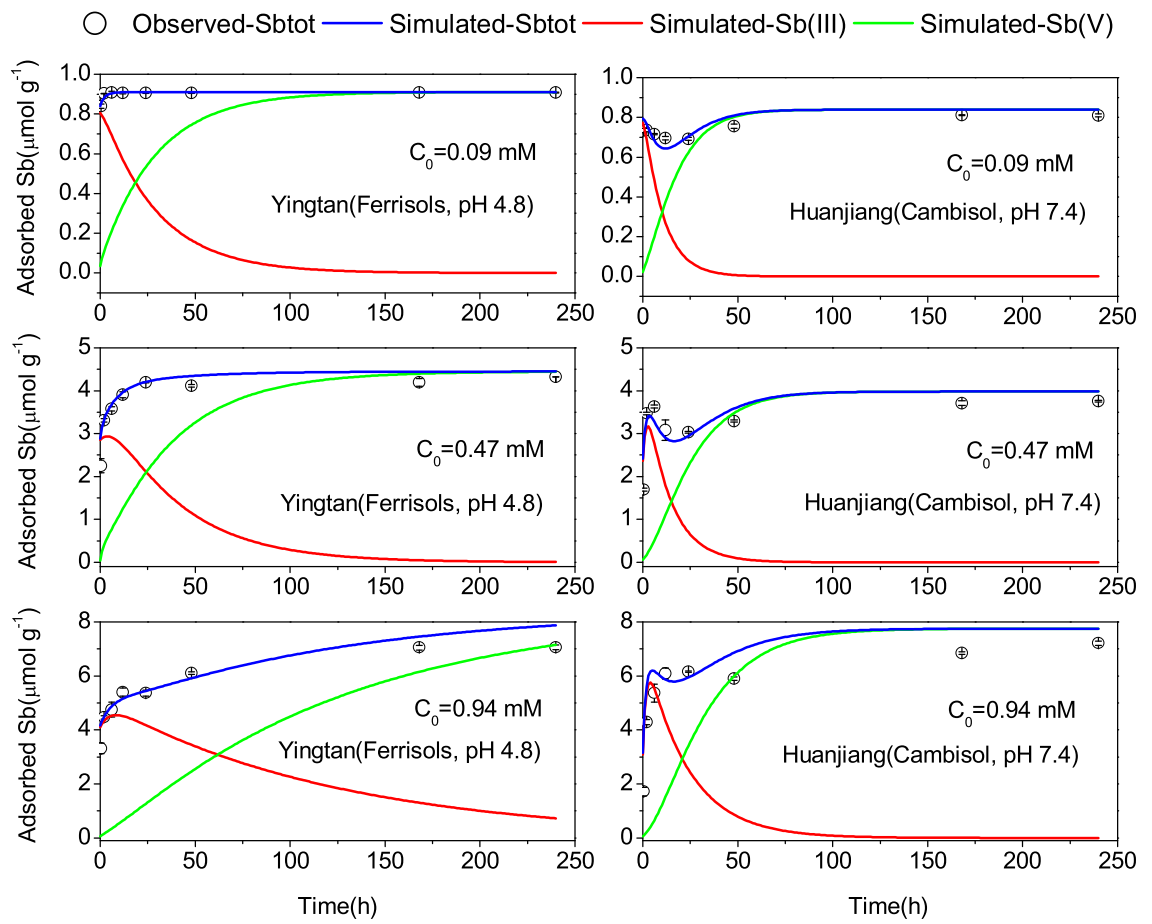

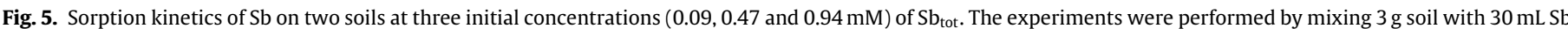

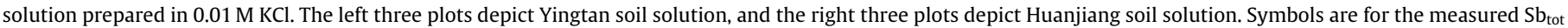

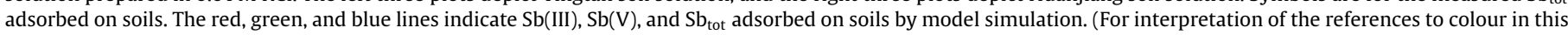
figure legend, the reader is referred to the web version of this article.)

the oxidation rate clearly influenced by the initial concentration of $\mathrm{Sb}$ (III). After $240 \mathrm{~h}$ reaction, almost all $\mathrm{Sb}$ (III) adsorbed on soils were oxidized to $\mathrm{Sb}(\mathrm{V})$ for the two lower initial concentrations $(0.09$, $0.47 \mathrm{mM}$ ), but it need more time for all $\mathrm{Sb}(\mathrm{III})$ to be oxidized when the initial concentration was $0.94 \mathrm{mM}$ (Fig. 4). At the three con- centrations $0.09,0.47$, and $0.94 \mathrm{mM}$ the oxidation rates of $\mathrm{Sb}(\mathrm{III})$ were 9.72E-06, 8.33E-06, and 3.89E-06 (Table 2). In Huanjiang soil, almost all $\mathrm{Sb}$ (III) was oxidized in about $150 \mathrm{~h}$ because of relatively higher oxidation rate. Overall, $\mathrm{Sb}(\mathrm{III})$ will be oxidized to $\mathrm{Sb}(\mathrm{V})$ fast after adsorbed onto the two soil surfaces and $\mathrm{Sb}(\mathrm{V})$ can be eas- 
Table 2

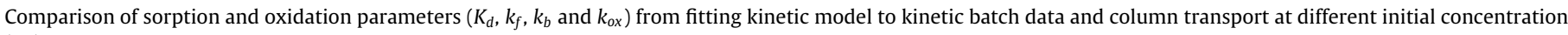
$\left(\mathrm{C}_{0}\right)$.

\begin{tabular}{|c|c|c|c|c|c|c|c|c|c|}
\hline Experiment & Soil & $\mathrm{C}_{0}(\mu \mathrm{M})$ & $K_{d 3}$ & $k_{f 3}\left(s^{-1}\right)$ & $k_{b 3}\left(s^{-1}\right)$ & $k_{o x}\left(s^{-1}\right)$ & $K_{d 5}$ & $k_{f 5}\left(s^{-1}\right)$ & $k_{b 5}\left(s^{-1}\right)$ \\
\hline \multirow[t]{6}{*}{ Batch } & Yingtan & 0.09 & 31.6 & 8.33E-04 & $2.78 \mathrm{E}-05$ & $9.72 \mathrm{E}-06$ & 10.0 & 3.39E-04 & $1.53 \mathrm{E}-05$ \\
\hline & & 0.47 & 5.0 & $5.56 \mathrm{E}-05$ & 1.67E-05 & 8.33E-06 & 1.6 & $2.22 \mathrm{E}-04$ & $1.53 \mathrm{E}-05$ \\
\hline & & 0.94 & 2.5 & $1.94 \mathrm{E}-05$ & 4.17E-05 & 3.89E-06 & 1.6 & $1.67 \mathrm{E}-05$ & $2.22 \mathrm{E}-06$ \\
\hline & Huanjiang & 0.09 & 20.0 & $1.11 \mathrm{E}-03$ & 2.78E-05 & $2.78 \mathrm{E}-05$ & 5.0 & $2.78 \mathrm{E}-05$ & 3.89E-06 \\
\hline & & 0.47 & 3.2 & $2.78 \mathrm{E}-04$ & $2.78 \mathrm{E}-05$ & $2.22 \mathrm{E}-05$ & 2.5 & $1.67 \mathrm{E}-05$ & 3.33E-06 \\
\hline & & 0.94 & 1.6 & $1.67 \mathrm{E}-04$ & $5.56 \mathrm{E}-05$ & $1.53 \mathrm{E}-05$ & 1.6 & $1.81 \mathrm{E}-05$ & 4.17E-06 \\
\hline \multirow{2}{*}{ Column } & Yingtan & 0.94 & 100.0 & 8.33E-05 & $2.78 \mathrm{E}-08$ & $1.39 \mathrm{E}-08$ & 100.0 & $2.22 \mathrm{E}-04$ & $1.39 \mathrm{E}-05$ \\
\hline & Huanjiang & 0.94 & 316.2 & 8.89E-05 & 4.17E-08 & 3.33E-08 & 794.3 & $9.72 \mathrm{E}-05$ & $2.78 \mathrm{E}-06$ \\
\hline
\end{tabular}

ily released into solution and then readsorbed in Huangjiang soil (Figs. 4 and 5).

\subsection{Breakthrough curves}

Fig. 6 shows the breakthrough curves of $\mathrm{Sb}(\mathrm{III})$ and $\mathrm{Sb}(\mathrm{V})$ in columns of the two soils. Extensive retention and low mobility of $\mathrm{Sb}(\mathrm{III})$ was found in the two soils before 100 pore volumes of Yingtan soil and 150 pore volumes of Huanjiang soil. This result was different with the result of $\mathrm{Sb}(\mathrm{V})$ study by Zhang et al. [28] in the same two soils. In their study $\mathrm{Sb}(\mathrm{V})$ can easily breakthrough the soil column of Huanjiang soil, while for Yingtan soil $\mathrm{Sb}(\mathrm{V})$ was extensive retention. Complete breakthrough, i.e. $100 \%$ recovery of that input concentration of $\mathrm{Sb}$, was observed in the Yingtan soil column after applying 180 pore volumes of $\mathrm{Sb}$ (III) solution. While for the Huanjiang soil column, Sb was far from complete breakthrough. In Yingtan soil column, almost no Sb effluent before the first 90 pore volumes. But after 90 pore volumes, the Sb breakthrough the column quickly, and the vast majority of $\mathrm{Sb}$ was $\mathrm{Sb}(\mathrm{III})$. This may because of red colloid formed in the soil column after applying 100 pore volumes of $\mathrm{Sb}$ (III) solution. And the main colloid Sb was $\mathrm{Sb}$ (III) and the colloid mainly composed of Fe-oxides (Fe weight percentage $8.69 \%$ ) which was analyzed by SEM-EDS. Earlier studies have indicated that colloid is an important factor influence heavy metals transport in soils $[41,42]$. Huanjiang soil has a larger adsorption capacity than Yingtan soil, which is consistent with the result of isotherms experiment (Table 1 ). The peak $\mathrm{Sb}_{\text {tot }}$ concentration in the effluent of Huanjiang soil column was only about $15 \%$ of the applied concentration after applying approximately 300 pore volumes of $\mathrm{Sb}$ solution. This is contrary to the transport behavior of $\mathrm{Sb}(\mathrm{V})$ in the same two soils [28]. It means that $\mathrm{Sb}$ (III) has strong mobility in acidic Yingtan soil with colloid of Fe-oxides, while on the contrary $\mathrm{Sb}(\mathrm{V})$ was more easily transport in calcareous Huanjiang soil. When leaching with $\mathrm{KCl}$ solution, almost no $\mathrm{Sb}(\mathrm{V})$ released from Yingtan soil column (Fig. 6), which is consistent with our kinetic experiment. This means that sorption of $\mathrm{Sb}$ (III) was irreversible especially in an anaerobic system, which was consistent with earlier studies $[12,19,35,43]$.

In Huanjiang soil column, the concentration of $\mathrm{Sb}(\mathrm{V})$ in the effluent solution was far below the input solution before the first 150 pore volumes. After that $\mathrm{Sb}(\mathrm{III})$ and $\mathrm{Sb}(\mathrm{V})$ concentration in effluent began to increase slowly till to replace the input solution by $\mathrm{KCl}$ solution. The concentration of $\mathrm{Sb}(\mathrm{V})$ was continuing increase until applying about 200 pore volumes of $\mathrm{KCl}$ solution. After 200 pore volumes of $\mathrm{KCl}$ input, most of the $\mathrm{Sb}$ leached out was $\mathrm{Sb}(\mathrm{V})$. In calcareous Huanjiang soil $\mathrm{Sb}(\mathrm{V})$ showed a non-equilibrium transport process as the extensive tailing and slow release during leaching [28]. In our experiment the extensive tailing and slow release of $\mathrm{Sb}(\mathrm{V})$ was more significantly due to the oxidation rate of $\mathrm{Sb}(\mathrm{III})$ and abundant of $\mathrm{Sb}(\mathrm{III})$ adsorbed before leaching. Ilgen et al. [44] have found that in berm soils with high organic matter content, $\mathrm{Sb}$ (III) will have a longer half-life compared to soils with low organic content. So Sb(III) sorbed on Huanjiang soil with high content of TOC might cause a long-term release of $\mathrm{Sb}(\mathrm{V})$. Mitsunobu et al. [26] have found that $\mathrm{Sb}$ was present exclusively as $\mathrm{Sb}(\mathrm{V})$ over a wide redox range (from $\mathrm{Eh}=360$ to $-140 \mathrm{mV}, \mathrm{pH} 8$ ) in the soil-water system. This means even in anaerobic conditions, $\mathrm{Sb}(\mathrm{III})$ might be oxidized to $\mathrm{Sb}(\mathrm{V})$ if there are oxidant such as Fe-Mn oxides exist in the system. Furthermore, we think it is unlikely that $\mathrm{Sb}(\mathrm{III})$ was oxidized by microbial processes in our system, as earlier studies have shown that a few bacteria able to oxidize antimony have been isolated from the environment [45] let alone in this anoxic conditions. Notably, in our experiment the two soils with widely natural minerals all have large surface areas, not only as adsorbent but also acting as strong oxidants in transforming $\mathrm{Sb}(\mathrm{III})$ to $\mathrm{Sb}(\mathrm{V})$. Overall, $\mathrm{Sb}$ (III) can easily breakthrough the vadose zone in anaerobic condition in acid Yingtan soils and may contaminate ground water, while $\mathrm{Sb}(\mathrm{III})$ sorbed on the calcareous Huanjiang soil might cause long-term release of $\mathrm{Sb}(\mathrm{V})$.

The model cannot well simulated $\mathrm{Sb}(\mathrm{III})$ and $\mathrm{Sb}(\mathrm{V})$ transport because of abundant of colloid carried Sb in the Yingtan soil column. While the model can well simulated $\mathrm{Sb}(\mathrm{III})$ and $\mathrm{Sb}(\mathrm{V})$ transport in Huanjiang soil column but overestimated the oxidation rate of $\mathrm{Sb}(\mathrm{III})$. Sorption rate coefficients $\left(K_{\mathrm{d}}\right)$ obtained from column BTCs are great larger than those from kinetic sorption data (Table 2), which is indicative of stronger equilibrium sorption in columns than in batch reactors. Compared with kinetic experiment, the oxidation rate coefficients $\left(k_{o x}\right)$ is higher in batch reactors than in columns because the column experiment was conducted in anaerobic conditions. Other factors such as low soil/solution ratio and increased spatial heterogeneity of sorption sites might also contribute to the observed discrepancy between reaction systems [30].

\section{Conclusions}

Understanding the mechanisms controlling the kinetic retention, transport and redox process of $\mathrm{Sb}(\mathrm{III})$ is prerequisite for evaluating the environmental risk of Sb contaminated soils. In this study, the kinetic batch and column experiment results clearly revealed that a majority of input $\mathrm{Sb}(\mathrm{III})$ was kinetically oxidized into $\mathrm{Sb}(\mathrm{V})$ on surface of soils in kinetic batch experiment under aerobic condition and a smaller amount of $\mathrm{Sb}(\mathrm{III})$ was oxidized into $\mathrm{Sb}(\mathrm{V})$ in saturated column experiment under anaerobic condition. $\mathrm{Sb}$ (III) can easily breakthrough the vadose zone in anoxic condition in acid Yingtan soils and may contaminate ground water, this should be concern as $\mathrm{Sb}(\mathrm{III})$ is more toxicity than $\mathrm{Sb}(\mathrm{V})$. While the $\mathrm{Sb}$ (III) sorbed on the calcareous Huanjiang soil should also be considered as the long-term release of $\mathrm{Sb}(\mathrm{V})$ will cause continuous pollution. Soil is the catalyst and oxidant promoted the oxidation of $\mathrm{Sb}$ (III) even under anoxic conditions especially in calcareous soils. The equilibrium-kinetic sorption and kinetic oxidation formulations were capable of describing the kinetics of $\mathrm{Sb}(\mathrm{III})$ reactions. But the reactive transport model was less successful in describing the transport of $\mathrm{Sb}$ in soil columns especially in Yingtan soil column as abundant of colloid carried Sb leaching from the column and our model did not consider colloid species. Additional reaction mecha- 
Observed-Sb(III)— Simulated-Sb(III) $\bigcirc$ Observed-Sb(V)-- - Simulated-Sb(V)
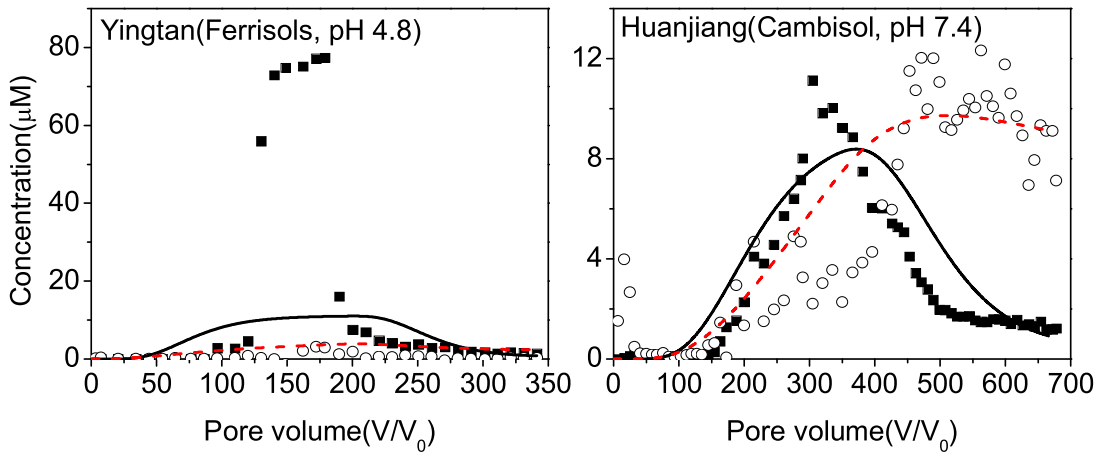

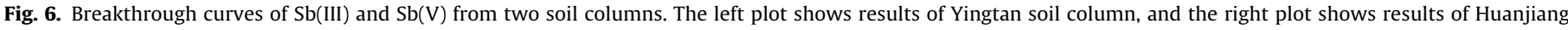

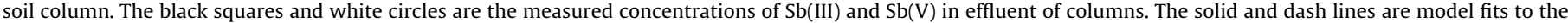
experimental data of $\mathrm{Sb}(\mathrm{III})$ and $\mathrm{Sb}(\mathrm{V})$, respectively.

nisms including colloid facilitated transport may contribute to the mobility of $\mathrm{Sb}(\mathrm{III})$ in soils.

\section{Acknowledgments}

The authors would like to thank Dr. Xueli Wu for chemical analysis. This work was financially supported by the National Natural Science Foundation of China $(41271506,41230858)$ and Key Research Program of the Chinese Academy of Sciences (KZZD-EW14). Dr. Hua Zhang was financially supported by the Recruitment Program of Global Young Experts (1000Plan).

\section{Appendix A. Supplementary data}

Supplementary data associated with this article can be found, in the online version, at http://dx.doi.org/10.1016/j.jhazmat.2016.05. 027.

\section{References}

[1] United States Environmental Protection Agency, Toxics release inventory, Doc. 745-R-00-007Washington, DC, USA, USEPA (1979).

[2] M. Filella, N. Belzile, Y.W. Chen, Antimony in the environment: a review focused on natural waters I. Occurrence, Earth-Sci. Rev. 57 (2002) 125-176.

[3] T. Gebel, Arsenic and antimony: comparative approach on mechanistic toxicology, Chem. Biol. Interact. 107 (3) (1997) 131-144.

[4] W. Hammel, R. Debus, L. Steubing, Mobility of antimony in soil and its availability to plants, Chemosphere 41 (2000) 1791-1798.

[5] D. Beyersmann, A. Hartwig, Carcinogenic metal compounds: recent insight into molecular and cellular mechanisms, Arch. Toxicol. 82 (2008) 493-512.

[6] K. Hockmann, R. Schulin, Leaching of antimony from contaminated soils, in: H.M. Selim (Ed.), Competitive Sorption and Transport of Heavy Metals in Soils and Geological Media, CRC Press, Boca Raton, FL, 2012, pp. 119-145.

[7] M. Filella, N. Belzile, Y.W. Chen, Antimony in the environment: a review focused on natural waters II. Relevant solution chemistry, Earth-Sci. Rev. 59 (2002) 265-285.

[8] Carlin Jr., Antimony, U.S. geological survey mineral commodity summaries (2000).

[9] M. He, X. Wang, F. Wu, Z. Fu, Antimony pollution in China, Sci. Total Environ. 421-422 (2012) 41-50

[10] S.C. Wilson, P.V. Lockwood, P.M. Ashley, M. Tighe, The chemistry and behaviour of antimony in the soil environment with comparisons to arsenic: a critical review, Environ. Pollut. 158 (2010) 1169-1181.

[11] G.P. Zhang, Case Studies of the Water Environmental Geochemistry of Mines in Guizhou Province (in Chinese), State Key Laborotary of Environmental Geochemistry, Institute of Geochemistry Ph.D Thesis, Chinese Academy of Sciences, Guizhou, 2005.

[12] A.K. Leuz, H. Monch, C.A. Johnson, Sorption of $\mathrm{Sb}(\mathrm{III})$ and $\mathrm{Sb}(\mathrm{V})$ to goethite: influence on Sb(III) oxidation and mobilization, Env. Sci. Technol. 40 (2006) 7277-7282

[13] A.C. Scheinost, A. Rossberg, D. Vantelon, I. Xifra, R. Kretzschmar, A.K. Leuz, H Funke, C.A. Johnson, Quantitative antimony speciation in shooting range soils by EXAFS spectroscopy, Geochim. Cosmochim. Acta 70 (2006) 3299-3312.

[14] C. Shan, Z. Ma, M. Tong, Efficient removal of trace antimony(III) through adsorption by hematite modified magnetic nanoparticles, J. Hazard. Mater. 268 (2014) 229-236.
[15] A.G. Ilgen, T.P. Trainor, $\mathrm{Sb}(\mathrm{III})$ and $\mathrm{Sb}(\mathrm{V})$ sorption onto Al-Rich phases: hydrous Al oxide and the clay minerals kaolinite KGa-1b and oxidized and reduced nontronite NAu-1, Environ. Sci. Technol. 46 (2) (2012) 843-851.

[16] J. Xi, M. He, C. Lin, Adsorption of antimony(III) and antimony(V) on bentonite: kinetics, thermodynamics and anion competition, Microchem. J. 97 (1) (2011) 85-91.

[17] S. Tserenpil, C. Liu, Study of antimony(III) binding to soil humic acid from an antimony smelting site, Microchem. J. 98 (1) (2011) 15-20.

[18] F. Quentel, M. Filella, C. Elleouet, C.L. Madec, Kinetic studies on Sb(III) oxidation by hydrogen peroxide in aqueous solution, Environ. Sci. Technol. 38 (10) (2004) 2843-2848.

[19] A.K. Leuz, C.A. Johnson, Oxidation of $\mathrm{Sb}(\mathrm{III})$ to $\mathrm{Sb}(\mathrm{V})$ by $\mathrm{O}_{2}$ and $\mathrm{H}_{2} \mathrm{O}_{2}$ in aqueous solutions, Geochim. Cosmochim. Acta 69 (5) (2005) 1165-1172.

[20] F. Quentel, M. Filella, C. Elleouet, C.L. Madec, Sb(III) oxidation by iodate in seawater: a cautionary tale, Sci. Total Environ. 355 (1-3) (2006) 259-263.

[21] J. Fan, Y. Wang, T. Fan, X. Cui, D. Zhou, Photo-induced oxidation of Sb(III) on goethite, Chemosphere 95 (2014) 295-300.

[22] J. Xi, M. He, K. Wang, G. Zhang, Adsorption of antimony(III) on goethite in the presence of competitive anions, J. Geochem. Explor. 132 (2013) 201-208.

[23] X. Wang, M. He, C. Lin, Y. Gao, L. Zheng, Antimony(III) oxidation and antimony $(\mathrm{V})$ adsorption reactions on synthetic manganite, Chem. Erde 724 (2012) 41-47.

[24] N. Belzile, Y.W. Chen, Z. Wang, Oxidation of antimony(III) by amorphous iron and manganese oxyhydroxides, Chem. Geol. 174 (2001) 379-387.

[25] J. Buschmann, S. Canonica, L. Sigg. Photoinduced oxidation of antimony(III) in the presence of humic acid, Environ. Sci. Technol. 39 (14) (2005) 5335-5341.

[26] S. Mitsunobu, T. Harada, Y. Takahashi, Comparison of antimony behavior with that of arsenic under various soil redox conditions, Environ. Sci. Technol. 40 (23) (2006) 7270-7276

[27] S. Mitsunobu, T. Harada, Y. Terada, $\mu$-XANES evidence for the reduction of $\mathrm{Sb}(\mathrm{V})$ to $\mathrm{Sb}(\mathrm{III})$ in soil from Sb mine tailing, Environ. Sci. Technol. 44 (4) (2010) $1281-1287$.

[28] H. Zhang, L.L. Li, S.W. Zhou, Kinetic modeling of antimony(V) adsorption-desorption and transport in soils, Chemosphere 111 (2014) 434-440.

[29] H. Zhang, H.M. Selim, Kinetics of arsenate adsorption-desorption in soils, Environ. Sci. Technol. 39 (2005) 6101-6108.

[30] H. Zhang, H.M. Selim, Modeling the transport and retention of arsenic (V) in soils, Soil Sci. Soc. Am. J. 70 (2006) 1677-1687.

[31] H. Zhang, H.M. Selim, Second-order modeling of arsenite transport in soils, J. Contam. Hydrol. 126 (2011) 121-129.

[32] D.L. Parkhurst, C.A.J. Appelo, Description of input and examples for PHREEQC version 3-A computer program for speciation, batch-reaction, one-dimensional transport, and inverse geochemical calculations: U.S. Geological Survey Techniques and Methods, (2013) book 6, chap. A43, 497 p., available only at http://pubs.usgs.gov/tm/06/a43/.

[33] Y.S. Ho, J.F. Porter, G. Mckay, Equilibrium isotherm studies for the sorption of divalent metal ions on to peat: copper, nickel and lead single component systems, Water Air Soil Pollut. 141 (2002) 1-33.

[34] J. Pilarski, P. Waller, W. Pickering, Sorption of antimony species by humic-acid, Water Air Soil Pollut. 84 (1-2) (1995) 51-59.

[35] M. Vithanage, A.U. Rajapaksha, X.M. Dou, N.S. Bolan, J.E. Yang, Y.S. Ok, Surface complexation modeling and spectroscopic evidence of antimony adsorption on iron-oxide-rich red earth soils, J. Colloid Interface Sci. 406 (2013) 217-224.

[36] J. Xi, M. He, C. Lin, Adsorption of antimony(V) on kaolinite as a function of pH, ionic strength and humic acid, Environ. Earth Sci. 60 (4) (2010) 715-722.

[37] S. Rakshit, D. Sarkar, R. Datta, Surface complexation of antimony on kaolinite, Chemosphere 119 (2015) 349-354.

[38] M. Tighe, P. Lockwood, The importance of non-crystalline hydroxide phases in sequential extractions to fractionate antimony in acid soils, Commun. Soil Sci. Plant 38 (11-12) (2007) 1487-1501 
[39] M.L. Pierce, C.B. Moore, Adsorption of arsenite and arsenate on amorphous iron hydroxide, Water Res. 16 (7) (1982) 1247-1253.

[40] S. Ambe, Adsorption kinetics of antimony(V) ions onto alpha- $\mathrm{Fe}_{2} \mathrm{O}_{3}$ surfaces from an aqueous solution, Langmuir 3 (1987) 489-493.

[41] Y. Zhu, L.Q. Ma, X. Dong, W.G. Harris, J.C. Bonzongo, F. Han, Ionic strength reduction and flow interruption enhanced colloid-facilitated $\mathrm{Hg}$ transport in contaminated soils, J. Hazard. Mater. 264 (2014) 286-292.

[42] X. Yin, B. Gao, L.Q. Ma, U.K. Saha, H. Sun, G. Wang, Colloid-facilitated Pb transport in two shooting-range soils in Florida, J. Hazard. Mater. 177 (2010) 620-625.

[43] M. Tighe, P. Lockwood, S. Wilson, Adsorption of antimony (V) by floodplain soils, amorphous iron(III) hydroxide and humic acid, J. Environ. Monit. 7 (12) (2005) 1177-1185.
[44] A.G. Ilgen, F. Majs, A.J. Barker, T.A. Douglas, T.P. Trainor, Oxidation and mobilization of metallic antimony in aqueous systems with simulated groundwater, Geochim. Cosmochim. Acta 132 (2014) 16-30.

[45] M. Filella, N. Belzile, M.C. Lett, Antimony in the environment: a review focused on natural waters III. Microbiota relevant interactions, Earth-Sci. Rev. 80 (2007) 195-217.

[46] M.B. Calle-Guntiñas, Y. Madrid, C. Cámara, Stability study of total antimony, $\mathrm{Sb}(\mathrm{III})$ and $\mathrm{Sb}(\mathrm{V})$ at the trace level, Fresen. J. Anal. Chem. 344 (1) (1992) 27-29.

[47] A. Amirbahman, D.B. Kent, G.P. Curtis, J.A. Davis, Kinetics of sorption and abiotic oxidation of arsenic(III) by aquifer materials, Geochim. Cosmochim. Acta 70 (3) (2006) 533-547. 